\title{
AUTÓEMBLÉMÁK CSOPORTOSÍTÁSA
}

\author{
Dömötör Csaba \\ egyetemi docens, Miskolci Egyetem, Gép-és Terméktervezési Intézet \\ 3515 Miskolc, Miskolc-Egyetemváros, e-mail: machdcs@uni-miskolc.hu
}

\begin{abstract}
Absztrakt
Ez a cikk az autóipari vállalatok emblémáiban fellelhetö motívumokat rendszerezi és bemutatja ezek márkaarculatban betöltött szerepét. Kitér a logó és embléma jelentésbeli különbségeire, ismerteti a tervezés fö szempontjait valamint bemutatja az uralkodó grafikai elemek által közvetíthetö üzeneteket. A kategóriákba sorolás az emblémák meghatározó szimbólumai szerint történik.
\end{abstract}

Kulcsszavak: autóipar, logó, embléma, márkaarculat

\section{Abstract}

This article organizes the motifs found in the logos of the representatives of the automotive industry and presents their role in the brand image. It covers the differences in meaning between the logo and the emblem, describes the main aspects of the design and presents the messages conveyed by the dominant graphic elements. Categorization is based on the defining symbols of the emblems.

Keywords: automotive, logo, emblem, branding

\section{Bevezetés}

Egy vállalat vagy márka piaci helyzetének szempontjából kiemelt jelentőségü, hogy azt a vásárlók vagy ügyfelek könnyen felismerjék, illetve meg tudják különböztetni a piaci versenytársaktól. Ennek egyik kiváló eszköze a brandet egyértelmủen beazonosítani képes, jól felismerhető és megjegyezhető, egyedi jel, mely ily módon a márka arculati alapeleme lehet.

\section{Logó, embléma és szimbólum}

A márkát beazonosító jelet a köznyelv leggyakrabban logónak nevezi, de sok esetben nem igaz rá az eredeti „logogram” szó definíciószerüen körvonalazható legfőbb tulajdonsága, miszerint ez egy szót vagy szókapcsolatot bemutató jelzés. De a logók lehetnek szóképek vagy abból származtatott jelek is. Közös jellemzőjük, hogy betükből állnak vagy felidézik azokat. A cikk témáját jelentő egyedi jeleket ezért nevezzük inkább emblémának, mely kifejezéssel tágabb fogalomként hivatkozhatunk a valódi betüket nem tartalmazó jelzésekre is, hiszen az embléma a grafikus jel maga. Ezen fogalmak mellett érdemes még megemlíteni a szimbólumokat, melyek szintén gyakran jelennek meg a vállalati arculatot képviselő emblémákban. A szimbólum elvont gondolattartalmat, sajátos jelentésátvitelt megtestesítő (szó)kép, vagyis egyfajta tömör vizuális üzenet. Az emblémák célja pedig épp az, hogy röviden kifejezzék egy cég vagy márka személyiségét, illetve arculatát. 


\subsection{Követelmények}

A profitorientált cégek elsődleges célja, hogy a fogyasztói igényeket kielégítő - vagy ezt ígérő - és ezáltal eladható termékek kidolgozásával nyereséget termeljenek. Ehhez egy jól megtervezett embléma hatékony támogatást képes nyújtani.

A számos követelmény közül legfontosabb a beazonosíthatóság, amit az egyszerü, de jól felismerhető motívumok segítenek leginkább. Az embléma - mint termék- kialakításakor stílusirányzattól függetlenül szinte minden esetben jó választás a „mindig divatos természet” valamilyen mértékü felidézése egy mintázat vagy színkombináció, jellegzetes formai elem, vagy csak egy jól bevált arány adaptációja által. A szemlélö tudatalattijában ugyanis az organikus formaalkotó elemek a megbízhatóságot és tartósságot testesítik meg. Mivel ezek olyan jellemzők, amit a legtöbb felhasználó keres egy-egy termék megvásárlásakor, már az emblémával érdemes ezt közvetíteni.

$\mathrm{Az}$ átadni kívánt üzenet könnyebb célba érését segíti, ha bizonyos követelményeket betartunk a tervezés során. Általánosságban az emblémákkal szemben az alábbi elvárások támaszthatók:

- Egyszerüség

- Megkülönböztethetőség

- Világos üzenet

- Eredetiség

- Megfelelő forma

- Jól kiválasztott színek

- Egy jó betütípus

- Időtállóság

- Sokszorosíthatóság

- Kicsinyíthetőség/nagyíthatóság

\subsection{A formák jelentése}

Míg például a szimbólumok konkrét jelentéssel bírnak, addig az egyszerübb geometriai formákhoz többnyire általánosabb képzettársításokat rendelhetünk. Így például az autóiparban nem véletlenül olyan gyakori az ellipszis/ovális/kör alak, hiszen ez pozitív érzelmi üzenetet hordoz. A végtelenség mellett hozzá kötődő fogalmak a barátság, kapcsolat, szeretet, de ugyanakkor nőiesség, varázslat és titokzatosság is. Az autóemblémák másik, szintén rendszeresen visszaköszönő geometriai eleme a pajzs, melynek uralkodó motívuma a háromszög, ami az izgalom, kockázat, veszély elfogadott jelképe, de emellett szimbolizálhatja az egyensúlyt és stabilitást is. A négyzet és ehhez köthető formák az erő, bátorság, biztonság, megbízhatóság, professzionalizmus, hatékonyság fogalomköréhez köthetők. A fő motívumként megjelenő függőleges vonalak férfiasságot, erőt és agressziót sugároznak míg a vízszintes vonalakhoz a közösség érzete és a nyugalom kötődik. Egy speciális forma a spirál, mely a növekedés, kreativitás, nyugalom és intelligencia megtestesítője. A természetes formákhoz pedig általánosságban az eredetiség, egységesség, egyensúly és frissesség fogalmai társulnak. Végül pedig absztrakt formákat alkalmazunk, ha az egyediséget és kidolgozottságot kívánjuk kiemelni. 


\section{Autóemblémák csoportosítása}

Az autógyártók többsége nagy múltra visszatekintő cégcsoport részeként müködik, így sok esetben egy-egy márka emblémája a tulajdonviszonyokat, a piacot, a divatot vagy éppen a felhasználói igényeket követve több változáson is átesett már napjainkig. Ezek a változások legtöbb esetben megtartják a fő motívumokat, de néhány esetben radikálisan új dizájnt hoznak. Jelen cikk többségében napjaink aktuális autóemblémáit dolgozza fel, de néhány - föleg magyar vonatkozású esetben visszatekint az elmúlt idők emlékeire is.

Az emblémák csoportosítására több lehetőség is kínálkozik, de esetünkben a fö formai elem, mint meghatározó motívum jelenti a besorolási szempontot. Természetesen léteznek olyan emblémák is, amelyek kettő vagy több típusba is beilleszthetők lennének, ezért ezeket külön csoportba sorolhatjuk. A továbbiakban ezen alapbesoroláson haladunk végig.

\subsection{Márkanévre utaló, verbális}

Egy cég vagy márkanév ismertségének növeléséhez a legkézenfekvőbb eszköz egy valódi „logogram” alkalmazása, ami egyértelmüen és betűkkel utal az elnevezésre. Ha a tervező a logótervezés ezen útját választja, sok esetben csak egy egyedi színnel és betütípussal, térbeliséggel vagy éppen befoglaló formával dolgozhat. Nem véletlen, hogy gyakran kombinálják ezt a típust valamilyen jellegzetes geometriai alakzattal.

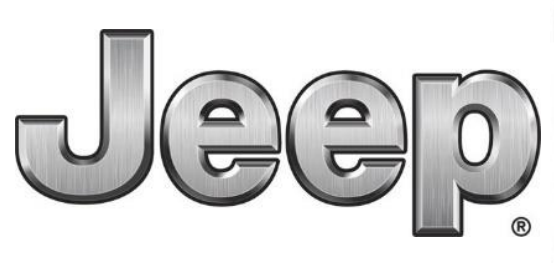

a)

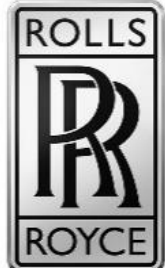

b)

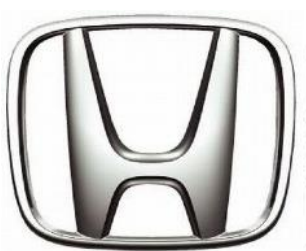

c)

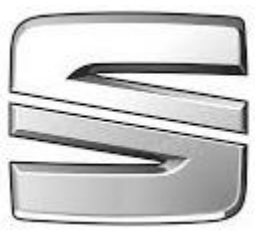

d)

1. ábra. Márkanévre utaló, verbális típusú emblémák

Az 1. ábrán látható példákon a Jeep logó letisztult és célszerü, mint maga a jármü. A Rolls Royce határozott téglalapba zárt logója, melyet további vízszintes vonalakkal tagoltak megbízhatóságot, kimértséget és nyugalmat sugároz. A Honda egyedileg tervezett betútípusú, ék alakban szükülö kezdőbetűje a lekerekített trapéz formában dinamizmust sugall csakúgy, mint a Seat logó, melyben szintén a márka stilizált kezdőbetüje dominál, de az átlós vonallal felosztva komoly hangsúlyt kap a sportosságot megjelenítő geometria is.

\subsection{Absztrakt, geometriai}

Absztrakt vagy geometriai formákat középpontba állítva már a márkanéven túlmutató, a márkaarculatot, cégfilozófiát tükröző vagy éppen a vállalat történetére utaló, akár elvont gondolattartalom is közvetíthető (2. ábra). A Toyota esetében például a két belső ellipszis szimbolizálja a vásárlók és a termék bizalomra épülö összefonódását, míg a külső a kihívásoknak való megfelelést követelő világot jelenti. De a gyártó rajongói felfedezni vélik benne a márkanév minden karakterét is [7]. A Mitsubishi geometriai eblémájában maga a japán fonetika köszön vissza, hiszen „mitsu” japán nyelven hármat jelent, a „hishi” pedig egy a szigetországban honos gesztenyefajt jelöl. A kettőből alkotott szóösszetétel jelentése pedig japánul gyémánt, amiben a vonatkozó nyelvtan szerint a középen lévő „h” hang helyett „,”-t ejtenek. Bizonyítéka ennek a három rombuszt formázó 
jelkép időtállóságának, hogy az eredeti - még nem autóipari - cég 1875-ös alapítása óta változatlan formában használják.

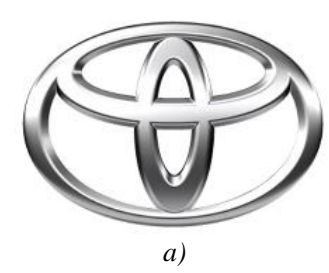

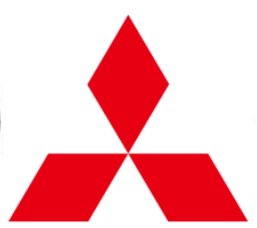

b)
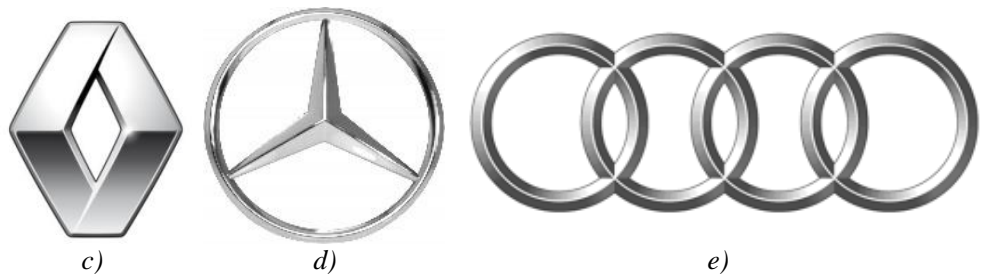

e)

2. ábra. Absztrakt és geometriai motívumok

Hasonlóan a rombusz alakzat dominál a Renault emblémájában, melynek eredeti változatát Victor Vasarely magyar származású festőművész tervezte 1972-ben, alapul véve a cég logójaként 1925-től használt feliratos gyémánt motívumot, ami így már egy Möbius-szalag képét idézi a végtelenség érzését sugallva. A Mercedes háromágú csillaga az egyik legismertebb jelkép, amit autókról ismerhetünk és az 1910-es évektől szimbolizálja a földön, vízen, levegőben megvalósuló motorizációt. Jóval prózaibb jelentéssel bír az Audi négy karikája, mely a négy nagy autógyár (Audi-Horch-DKWWanderer) 1932-es egyesülésére emlékeztet.

\subsection{Felidéző}

Sokkal megfoghatóbb tartalommal bírnak, a különféle, már jól ismert, valós alakzatokat, sziluetteket vagy mintákat használó, de egyszerüsített geometriával megvalósuló felidéző típusú emblémák (3. ábra). Valójában ezek esetében sem mindig egyértelmü a mögöttes jelentés, de minden esetben elmondható, hogy nem egy bonyolult fogalmat, hanem egy-egy kézzel fogható tárgy képét stilizálják. A legismertebb félreértés a $\boldsymbol{B} \boldsymbol{M W}$ utoljára 2020-ban módosított, de föbb grafikai alapelemeit tekintve több, mit 100 éve változatlan logójához köthető, aminek színei és mintája Bavaria (Bajorország) illetve a Bajor Szabad Állam kék-fehér mintás zászlajára utal, míg ugyanakkor az eredeti vállalat kör alakú emblémáját viszi tovább [7]. A több forrásban is tévesen említett forgó repülőgép-propeller pedig csak egy 1929-es reklám miatt került be a köztudatba, bár tény, hogy a gyártó eredetileg valóban repülőgépmotorokat készített és az említett hirdetés is erre utalt vissza.

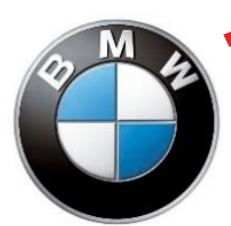

a)

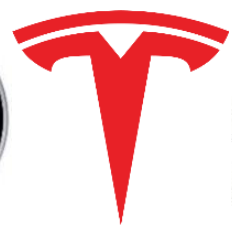

b)

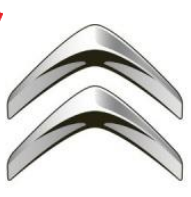

c)

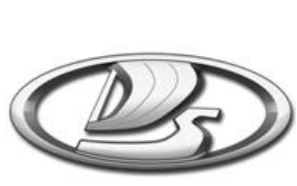

d)

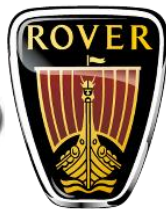

e)

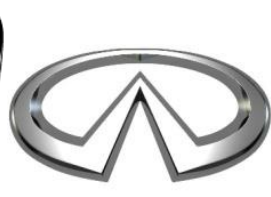

f)

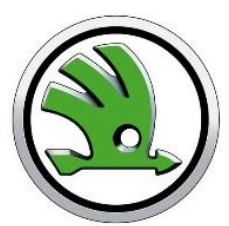

g)

\section{3. ábra. Példák felidézö típusú autóemblémákra}

A tradicionális autógyártók mellett folyamatosan lépnek a piacra kisebb-nagyobb cégek, amelyek általában egy-egy szükebb szegmensben próbálnak boldogulni. Legjellemzőbb a szupersportautók kategóriája, amiben számos törpevállalkozás tevékenykedik. Ezektől eltérő, de 2003-as alapításával még igencsak fiatalnak mondható amerikai nagyvállalat a Tesla Inc., ami a Szilícium-völgy high-tech cégei közt az első autógyártó. A kizárólag tisztán elektromos meghajtásra épülő jármüveken található „T” betüt formázó logójuk a Nikola Tesla szerb származású mérnök által feltalált elektromotor 
keresztmetszetének egy cikkét ábrázolja. Hasonlóan egy müszaki megoldást idéz fel a Citroën emblémája, amiben a fordított kettős V-alak az alapító André Citroën nyílfogazású fogaskerékszabadalmára utal.

A régmúlt tradícióira utalnak a nagy távolságok megtételére alkalmas hajózást felidéző emblémák. Érdekes egyezőség figyelhető meg, hiszen a hódítás erejét a Lada és a Rover emblémáján is egy viking vitorlás hajó testesíti meg. Előbbi esetében csak egy stilizált sziluett ismerhető fel, hiszen az eredeti cirill betüs $V A Z$ felirat (BA3) első betüjét formálták hajó alakúra. [6]

A megbízhatóságot sugalló hosszútávú használatra emlékeztet az Infiniti logója, mely a végtelenséget szimbolizáló ellipszisbe ágyazza a márkanév stilizált „I” betüjét, ami erre ráerősítve egy végtelenbe vesző egyenes útban ölt formát. Az autózáshoz nem kapcsolódik viszont a Škoda emblémája, mely eredetileg egy tollas fejdíszü indián harcost idézett fel, később ennek kontextusa szárnyas nyílra módosult, de mindkét esetben a hitelességet és a sikeres versengést hivatott szimbolizálni.

\subsection{Természeti}

A természetben fellelhető motívumokat alkalmazó autóemblémák sorában jellemzően az állatvilágból származó analógiákkal találkozhatunk, de az autógyártás történetében rendszeresen visszatérö motívum volt a jellegzetes, masszív, fényes leveleiröl ismert növényböl, vagyis a babérágakból font koszorú is.

Az állatvilágból származó gyakori példák között említhetjük repüléshez kapcsolódó szárnyakat és madarakat, de kiemelt szerep jut a közlekedésben jól bevált lovaknak is. Gyakran alkalmaznak a gyártók ragadozókat, de a mitológiai lényekre is több példát találunk. A növényevő állatok közül a kérődzőkre utaló motívumok alkotnak még egy nagyobb halmazt, míg a sort a csúszómászók kategóriája zárja.

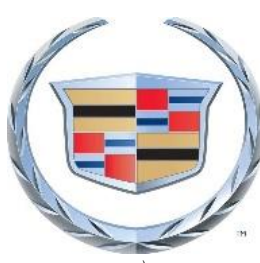

a)

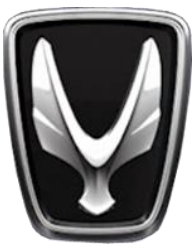

b)

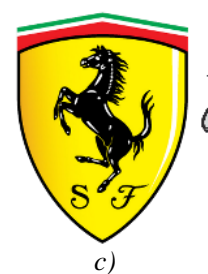

c)

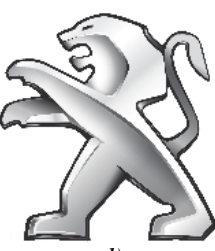

d)

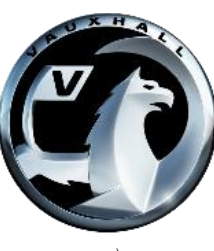

e)
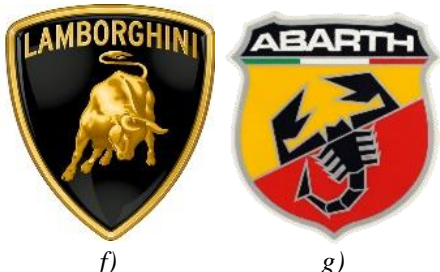

4. ábra. Természeti motívumok alkategóriái: a) babérkoszorú, b) szárnyak és madarak, c) lovak, d) ragadozók, e) mitológiai lények, f) kérődzők, g) csúszómászók

Bár most kifejezetten a grafikai elemekkel megjelenített természeti motívumokra fókuszálunk, érdemes megemlíteni, hogy az autógyártók előszeretettel választanak típusneveket is a természetből. Így például számos Volkswagen személyautó nagy áramlatokról kapta a nevét (Passat, Golf, Bora). A Renault Kangoo kisáruszállítója esetén pedig rögtön a jól ismert erszényes állatra asszociál az ember, de ehhez hasonlóan a „kicsi és cuki” benyomásra tud ráerősíteni a Fiat is azzal, hogy Panda néven forgalmazza városi kisautóját, bár nevét az utazók római istennőjéről, Empandáról kapta.

\subsection{Vegyes}

Szigorúan véve az emblémák nagyobbik része besorolható lenne ebbe a kategóriába, hiszen sok esetben több motívumból tevődik össze egy-egy ilyen márkajelzés. Legtöbbször maga a márkanév vagy annak kezdőbetűi hordozzák, vagy csak egészítik ki a formai alapelemet. De csak akkor soroljuk 
ebbe a kategóriába az adott emblémát, ha ezen két vagy több alapmotívum közel egyforma hangsúllyal bír. Az 5. ábrán ilyen logókat láthatunk. A Hyundai esetében a középen uralkodó „H” betü és az azt befoglaló ellipszisen túl még van egy valójában felismerhetetlen tartalom. Ez pedig az, hogy a márka kezdőbetűjét formázó középső alakzat (5.a ábra) egyúttal két egymással kezet rázó férfit szimbolizál, ami az elégedett ügyfél és a vállalat közti szoros kapcsolatra utal [7]. Azonban a többség előtt ez a jelentés többnyire rejtve marad, ezért is maradt ez a logó ebben a kategóriában. Az 5.b-c-d ábrákon bemutatott Nissan, Ford és Dacia logóit szintén a befoglaló forma és a benne elhelyezkedő felirat azonos ereje miatt sorolhatjuk ide.

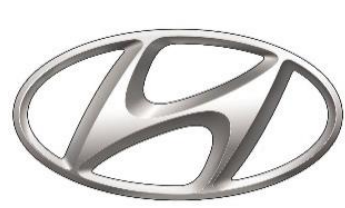

a)

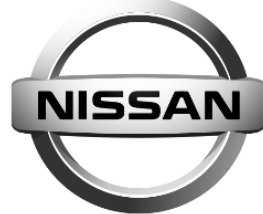

b)

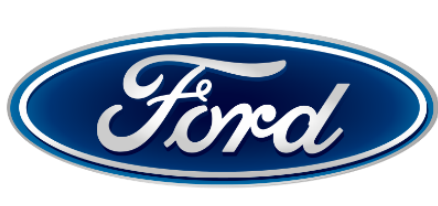

c)

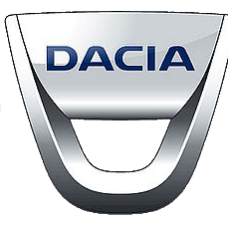

d)

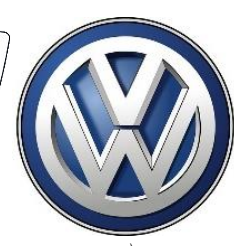

e)

5. ábra. Vegyes autólogók

A Volkswagen logója hasonlít ehhez, de ebben már olyannyira sikerült egy zárt körben egymásba integrálni a „Volk” (nép) és „Wagen” (gépkocsi) szavak kezdőbetüit, hogy ezen motívumok így már együtt alkotnak egy új egységet, amiben különös módon sokan már észre sem veszik mindkét betüt.

\section{4. Összefoglalás}

A márkajelek legfontosabb feladata, hogy értéket közvetítsenek. Megfelelő motívumok választásával segítik a kívánt üzenet átadását, másrészt pedig javítják az embléma megjegyezhetőségét is. Az autóemblémák feldolgozása tovább folytatódik és egy későbbi cikkben a természetből adaptált jelképek részletesen is bemutatásra kerülnek majd.

\section{Köszönetnyilvánítás}

A cikkben ismertetett kutatómunka az EFOP-3.6.1-16-2016-00011 jelü „Fiatalodó és Megújuló Egyetem - Innovatív Tudásváros - a Miskolci Egyetem intelligens szakosodást szolgáló intézményi fejlesztése" projekt részeként - a Széchenyi 2020 keretében - az Európai Unió támogatásával, az Európai Szociális Alap társfinanszírozásával valósul meg.

\section{Irodalomjegyzék}

[1] Heptinstall, S.: Car Marques: A Graphic Guide to Automotive Logos and Emblems, Motorbooks, 2018, ISBN: 0760362457

[2] Wheeler, A.: Designing Brand Identity, John Wiley \& Sons, Inc. 2009, ISBN 0470401422

[3] Budelmann, K.: Brand Identity Essentials, Rockport Publishers, 2010, ISBN: 1592535781

[4] Orgoványi, G.: Design és tipográfiai alapok, Tervezőgrafika II. tananyag, 2010 http://centroszet.hu/tananyag/tervgrafika2/212_a_renault_log_trtnete.html

[5] https://listcarbrands.com

[6] Dömötör, Cs., Péter, J.: Természeti elvek az analógia alapú tervezésben, GÉP, Vol. 63, No. 12., ISSN 00168572, Miskolc, 2012. november, pp. 29-32.

[7] https://vancello.blog.hu/2011/07/20/igy_szuletett_a_lada_logo 